Article

\title{
Beyond Essentialist Interreligious Education: Insights with a Whiteheadian Perspective of Multiplicity
}

\author{
Joung Chul Lee \\ Pacific School of Religion, Berkeley, CA 94709, USA; jclee429@gmail.com \\ Received: 9 May 2019; Accepted: 24 June 2019; Published: 26 June 2019
}

\begin{abstract}
In the late twentieth century, interreligious education emerged as a way to transform one's attitude toward other religions and reduce religious prejudice. This article addresses the philosophical aspects of this practice, in particular the problems that arise when an essentialist approach is accommodated. The problems include the why (philosophical rationale), the who (subject and participant), the what (content), and the future (purpose). In response, the author explores how a relational approach grounded in a Whiteheadian philosophy of multiplicity would allow us to understand interreligious education differently. The article finds that a relational approach can help us imagine and embody interreligious education in a more humanizing, inclusive, and transformative way.
\end{abstract}

Keywords: interreligious education; essentialism; relationalism; Whitehead; multiplicity

\section{Introduction}

This article addresses metaphysical and epistemological questions about the practice called interreligious education. What understandings of the nature of religious human beings ground interreligious education? How do we understand the nature of religion and faith? What assumptions do we make about religious identity and the process of learning and formation? What do we want interreligious education to achieve? Exploring these questions is a challenging yet highly important task, especially in the context of postmodern society, for it offers us an opportunity to look critically at our current practice of interreligious education and to shed light on the way forward (Durka 2010, p. 1).

This article basically explores how these questions would be answered differently by two different philosophical approaches: an essentialist approach and a relational approach. It asks how the practices of interreligious education can be intended, interpreted, and envisioned differently according to one's understanding of things, the world, and the relationship between the two. I especially choose these two approaches and discuss them side by side because the work of interreligious education is intrinsically intertwined with the tension between these two approaches. The origin of this tension lies in what we call religion - what we mean by it and how we define it. The essentialist and relational approaches to interreligious education are closely related to the two tendencies or attitudes that incline humans to religion. One attitude assumes that religion is a fixed and objectifiable entity, the other that religion is a changing and irreducible entity. The former highlights the essence of a religion, whereas the latter underlines lived religion or what Wilfred Cantwell Smith (1963) calls "religion as personal faith" (p. 194).

These two attitudes to religion are manifested in the essentialist approach and the relational approach to interreligious education. Each approach affects education in a radically different way. Interreligious education necessarily deals with religion; therefore, how to understand religion affects every aspect of this education, including its aim, goal, rationale, method, content, practice, etc.

The ultimate motive for pursuing this research is the desire to provide a conceptual grounding for the practice of interreligious learning and education in a way that highlights the fluidity and 
interconnectedness of religion and religious identity - that is, warning against the tendency to be haunted by essentialism and instead offering a vision of this learning as it can be experienced using a relational approach. Rachel S. Mikva (2018), professor at the Chicago Theological Seminary, rightly points out that resisting essentialism is one of the key challenges we encounter in interreligious studies and engagement. She notes, "Our challenge of interreligious literacy is the tendency to essentialize, downplaying intragroup diversity and ignoring the ways in which lived tradition is not fully represented in texts and formal religious teachings" (p. 132). This is also true in interreligious education. In such education, it is important to stay focused on the values and significances of encountering lived religion. In that way, participants can learn the diversity, complexity, and depth of a religion. The purpose of this research is, thus, not merely to show how the practice can be different by adopting different theoretical approaches. It is also to examine what kinds of limitations arise with an essentialist approach and how a relational approach offers pathways by which to move beyond some of the fundamental problems that an essentialist approach creates.

In what follows, I first briefly explain interreligious education to provide readers with the context of my research. Second, I explain how an essentialist approach appears in the discourse and what problems arise. Third, I show how interreligious education can be interpreted and imagined differently through a relational approach. In particular, I engage with a Whiteheadian relational approach and his concept of multiplicity. Lastly, I discuss how this latter relational approach can provide a way to overcome the limitations of an essentialist approach and help educators imagine and embody interreligious education in a more humanizing, inclusive, and transformative way. This research engages largely with the literature in the field of religious education but also addresses works in philosophy, philosophy of religion, and interreligious studies. The conclusion relies mainly on theoretical assumptions, so I hope that this research can be substantiated in the future by an empirical follow-up study.

\section{A Brief Introduction to Interreligious Education}

What do I mean by interreligious education, and in what particular academic context am I discussing it? My abbreviated explanation of interreligious education is: (a) learning together; (b) to live together; and (c) by exchanging religious perspectives with one another (see Boys and Lee 2006; Kujawa-Holbrook 2014; Van der Ven 1994).

First, the core of interreligious education is learning together. The point of such education is not learning about, but learning from and with the other through direct encounter and engagement. Initially, scholars such as Henry E. Kagan $(1950,1952)$ and Gordon Allport (1954) examined this method in the context of World War II in search of ways to reduce anti-Semitism. Recently, this method has regained attention and has been practiced chiefly in the context of a multireligious society in which hostility and terror threaten people's daily lives. Educators such as Mary C. Boys and Sara S. Lee (Boys and Lee 1996, 2006) and Eboo Patel and his colleagues (Patel and Brodeur 2006; Patel 2007; Patel and Meyer 2017) have greatly helped us to rediscover the effectiveness and the necessity of this learning method.

Second, interreligious education is generally known as an effective way to teach the participants skills, knowledge, and attitudes that help them live with other religious people. This point is well described by Sheryl A. Kujawa-Holbrook (2014). She articulates the effects of this education as "[acquiring] the knowledge, the attitudes and skills needed to interact, understand, and communicate with persons from diverse religious traditions" (2). She goes on to say that, through this education, participants learn ways in which "to function effectively in the midst of religious pluralism and to create pluralistic democratic communities that work for the common good" (2). Duncan Wielzen and Ina Ter Avest (Wielzen and Avest 2017) also articulate that this education equips the learners with "adequate social skills necessary for living together harmoniously in plural milieus" (3). By necessary skills they refer to "the ability to resolve conflicts peacefully, to argue, defend or critically assess any given moral position, and to value diversity as an enrichment to culture and society" (3). In short, 
by learning from and with religious others, one becomes equipped with competencies through which one is able to live peacefully with others.

Third, one of the important characteristics of this interreligious education is that it invites participants to come and learn by sharing their religious perspectives with one another. Johannes Van der Ven (1994) notes that the key to this educational model is "the perspective exchange" (p. 253). This "perspective" can also be interpreted as one's faith, a personal and holistic way to respond to transcendence (Smith 1963; Fowler 1981; Panikkar 1999; Heschel 1966). In sum, interreligious education refers to an educational activity that invites people from different religious backgrounds to learn together, that encourages them to share their religious views, identities, and experiences with one another, and that, therefore, helps them learn how to live with one another.

The World's Parliament of Religions in 1893 is known as the first intentional interreligious gathering in modern Western society, but it did not lead to the rapid appearance of interreligious education. It was only during the 1930s and 1940s that practitioners and scholars began to look at religious education in a religiously and socially pluralistic society (Kujawa-Holbrook 2014, p. 6). One of the earliest researchers who practiced and studied interreligious education was Henry E. Kagan in 1950s, who was a rabbi and psychologist. Scholars such as Marius C. Felderhof (1985); Norma Thompson (1988); and Karl E. Nipkow (1991) subsequently researched religious education in relation to religious pluralism, and their work foreshadowed the emergence of interreligious education in the late 1980s and early 1990s. In the 1990s and 2000s, discussions and practices of interreligious education arose in earnest, and interest in it has been ever growing since (e.g., Van der Ven and Ziebertz 1994; Boys and Lee 1996; Sterkens 2001; Boys and Lee 2006; Berling 2004; Patel and Brodeur 2006; Patel 2007; Pollefeyt 2007; Wielzen and Avest 2017; Pugliese and Hwang 2017).

\section{An Essentialist Mind Lurking Beneath the Surface}

Although interreligious education has been practiced and researched for a few decades, one of the questions I, as an educator and researcher, encounter most often is this question: "Is this education safe?" In asking this, people do not so much have physical safety in mind, although that can be an important issue in some contexts. Rather, they are concerned about their identity. They wonder whether their present religious identity would be adequately protected in such educational exchanges. Mohammed Abu-Nimer and Renáta Katalin Smith (Abu-Nimer and Smith 2016) once described such a response as people's "fears of conversion or of pupils losing their own faith(s)" (p. 398). For such people, education that does not complicate one's identity but simply strengthens it is, somehow, "safe" education, while that which might potentially shake one's religious identity is "dangerous."

This "safety/danger" mentality is seen not only in people who are unfamiliar with, or object to, interreligious education. It is also often seen in those who strongly affirm it. When one of my colleagues told me with excitement and relief, "A recent research says that interreligious education almost never makes people, even young kids, change their religion!" the message was clear: Interreligious education is "safe" education. Such a mentality is also lurking under the rhetoric that highlights interreligious education as an activity that transforms attitudes and deepens (or strengthens) faith (e.g., Boys and Lee 1996, 2006; Kujawa-Holbrook 2014). This statement might be generally right, but the "safety/danger" mentality is apparent in its word choices. By using "transform" to describe attitudes and "deepen" to describe faith, the statement gives the impression that it is only the attitude that changes, not faith: faith is only consolidated — not necessarily changed—and, thus, safe. Except for Johannes Van der Ven (1994), who argues that interreligious education is based on humanistic values such as freedom that gives one "the right to change one's own religion," few scholars have acknowledged how this education can be radically transformative in regard to one's faith, religious identity, or commitment (Van der Ven 1994, pp. 253-54).

Interestingly, my colleague's standard of judgment is intrinsically the same as the standard used by those who are opposed to, or reluctant to, embrace interreligious education. Although their stances toward interreligious education are different (as in yes, no, or I'm not sure), underlying their judgment 
is the same concern, of whether or not this kind of education is likely to affect one's religious beliefs and commitments. Their internal and normative question is the same: Is this education "safe"?, or will this education properly protect the essence of my religious identity? ${ }^{1}$

At the root of this "safety/danger" mentality is the essentialization of religion or religious essentialism. Essentialism has been widely discussed in various academic fields, but the basic meaning of essentialism as used in these disciplines remains analogous. In sociology, for example, Stephen Fuchs (2001), defines it as a belief that "things are what they are because that is their nature, essence or definition" (3). In psychology, Lisa Chalik, Sarah-Jane Leslie, and Marjorie Rhodes (Chalik et al. 2017) define (psychological) essentialism as "the belief that certain categories have an underlying nature, or 'essence,' that gives rise to the members' shared properties, and makes them fundamentally distinct from other kinds of things" (p. 1178). In the same manner, religious essentialism implies a belief that there are core elements one has to hold to be a member of a religion. It is also a belief that each religion has its own clear and closed boundary that distinguishes those who are "in" from those who are "out." People with this mentality believe that religious identity has a clear "essence" that cannot and should not be changed or lost. In this essentialist understanding, this essence is impaired or corrupted - therefore, in danger - if it is affected by outside influences.

It is in this sense that essentialist-minded people find it intimidating to interact with religious others. They are concerned whether such interactions may have any impact on their essential understanding of their religion. However, a careful examination of this essentialist approach reveals the potential for several problems, problems I call the why, the who, the what, and the future.

First of all, there is a problem of the why-the rationale for interreligious education. An essentialist understanding of religious identity may acknowledge the plurality of religion, but does not offer any necessary, ontological reason for interreligious interaction. In this approach, the reason for interreligious learning and interaction remains an ethical or political matter, but not an ontological one. People may know both themselves and the others better and experience reduced misunderstanding and conflict among one another as a result of interreligious education; but philosophically speaking such an effort is not necessary for their own existence. Its ontology can be encapsulated as "standalone," which means that things are "independent of relationships, context, time, or observer" (Fuchs 2001, pp. 12-13). Thus, interreligious learning and living can be considered optional for their existence. People may choose this practice for political correctness, based on their ethical imperatives, or as a survival tactic, but not for ontological reasons. This means that there is a possibility that when the rigidity of people's religious identity is challenged, their political and ethical imperatives become secondary-as do the peace of society and, in the worst-case scenario, the well-being of all.

Another potential problem lies in a question of the who-the subjects of interreligious education. An interesting question regarding the practice of interreligious education is this: for whom is this education planned? Is this education for human beings or for institutionalized religions? If one understands that the essence of Christianity, for example, is fixed, invariable, and shared with all other Christians, and that the same is true of the essence of Buddhism, then interreligious education may be understood as a venue in which Christians and Buddhists exchange the "essences" of their religions, or the Christianity and the Buddhism. In such a situation, the lived experiences of the participants may be shunned, unless their stories fit perfectly into the orthodox narratives of their tradition. In the same manner, interreligious education will not be considered to be a place to bring their internal struggles and questions with their religions. Only the "right" stories of the participating religions will be welcome. If this is the case, then such an education should be identified as an education for institutionalized religions as distinct from an education for participants. The problem of the former-or the problem of not distinguishing these two approaches-is that interreligious education may become a

1 This claim does not mean that everyone who engages with interreligious education is bound by the "safety/danger" mentality. The point is that such a mentality can operate as a psychological background for all of those who affirm, disapprove of, or defer conducting or participating in interreligious education. 
place of reductionism and categorization, which dehumanizes the participants and essentializes their lived experiences in different contexts.

This problem of the who leads to another problem, which is the matter of who is invited and who is not. If interreligious education is planned with this essentialist-minded pluralism in mind and understood as an education between institutionalized religions, then this education does not offer a place for those who do not identify themselves with major religions such as atheists, "nones," "spiritual but not religious," "multiple religious belonging," or those who adhere to teachings such as Confucianism or Taoism, which are quite different from the Western concept of religion. It has been a truism that one needs to have a clear religious identity in order to participate in interreligious interaction. For instance, Abraham Joshua Heschel (1966) emphasized, "The first and most important prerequisite of interfaith is faith" (p. 123). Leonard Swidler (1991) also underlined the idea that the participants "must come close to the dialogue as persons significantly identified with a religious or ideological community" (p. 65). Other people can join, but, says Swidler, the resulting event should then not be called "interreligious" (p. 65). However, such a view reduces the function of interreligious education and excludes a large number of people who live in a world that is full of religious symbols, concepts, stories, and people who eagerly but in different ways and to different extents engage with those elements.

Another issue we encounter with an essentialist understanding of religion is a matter of the what-what are the contents that participants learn? People argue that interreligious education helps participants learn about the other religion as well as their own religion. As I have already noted, the essentialization of religion would make people pay attention to the representational knowledge of the religion, including doctrines, laws, histories, and confessions. However, these aspects are actually not all there is to know about the religion. They are, so to speak, the historically, politically, and most widely agreed upon aspects of knowledge about the religion. However, they cannot, and should not, be equated with the whole of the religion. The religion is greater than the sum of such representational knowledge. I suggest that it is epistemologically unjust to argue that people can learn a religion simply by acquiring that kind of information. A religion consists of countless human lived experiences. Those experiences are entangled in a complicated way, and because of this they interact with one another, meaning that the religion is constantly shifting.

Lastly, an essentialist understanding of religion raises a question of the future. What will this education look like after the participants successfully attain the "essence" or "core knowledge" of their religion and the other's religion? There are two related issues here. One is about the future goal of interreligious education. What will we do after we have learned the essential teachings of the other religion? Additionally, what if that "correctly understood" knowledge of Islam, for example, is accepted as "incorrect" by Hinduism? Will such an effort be able to eliminate violence? The other issue concerns what will happen next, once participants gain full "correct knowledge" of the other religion. Will there be any other reason to meet, interact with, and learn from the other? Will the participants after all eventually accomplish "living together"? If so, how? What will sustain our "living together"? An essentialist approach does not give us a satisfying answer to these questions. Rather, such an approach suggests that such inter-religious contact would be restricted to an event-centered activity.

Overall, assuming religion to be an independent, closed, and fixed system and religious identity to be a subordinate of that system, creates many concerns and restrictions in interreligious education. At worst, interreligious education may end up as a mere accessory, dehumanizing, excluding, representational, and event-centered activity. Such education may help us apply our learning in the presence of the other, but it will not necessarily invite us to share our faith with the other. Religious literacy among participants may be increased, but that knowledge may not extend to "living together." One part of the goal of this education is to increase understanding of the other. However, what it may actually achieve, explicitly or implicitly, might include reproducing and strengthening sameness and reducing difference and lived reality. The sameness, the essence, the core about which people are so concerned, may be protected, but people may lose the stories that are carved deep into their minds and 
bodies-their individual, unique, and idiosyncratic embodiment of religion. The tenets of a religion might be valued thanks to such education, but lived experiences would be trivialized or overlooked.

Thus, for interreligious education to be successful, the challenge is to extend an invitation to those who do not identify themselves with any organized religious groups, those who do not have any essences to protect, and those who understand themselves as "becoming" rather than "being." Unless it is open to those who are not bound by tradition, interreligious education, which was begun with the intention of celebrating diversity, is, ironically more likely to restrict our ability to deepen our experience by excluding the richness of diverse realities.

\section{Philosophy of Multiplicity: A Whiteheadian Relational Approach}

Relationalism is a radically different way to interpret and reconstruct the world. The core value of essentialism is the ability to stand alone, but that of relationalism is togetherness. In this perspective, what is real is not the "essence" that is intrinsic and immaterial. What is real is the I and the You-our bodies and our relatedness. Its ontology affirms that things are never the "shadows of Ideas" but univocal and real events. Their relatedness to neighboring objects is the proof of their existence and reality. Stephen Fuchs (2001) describes this relationship as follows: "Things are what they are because of their location and movement in a network" (p. 16). In this worldview, interreligious education, or for that matter any kind of interreligious encounter, is not a simple exchange of the "essences" of the religions. That is a hollow illusion. Interreligious encounter is, rather, a venue in which the participants-their individual bodies that carry their unique memories, experiences, and narratives gained from various events that have happened in particular times and spaces-meet one another. Here they discover and create their physical, spiritual, political, cultural, and religious locations and relations with the other. Thus, interreligious encounter is not only inter-religious, but also inter-personal, inter-spiritual, and inter-cultural. It is a holistic encounter.

Relationalism is not monolithic. There are multiple versions of it. From Buddhist philosophy to (post)structuralism, from developmental psychology to sociology, relationalism appears in different contexts with slightly different slants, although all versions of relationalism are generally opposed to substantialism and essentialism. Of these many versions, I am attempting to reframe interreligious education with what I call a theory of multiplicity. Multiplicity deepens relationalism as it highlights not mere connectedness but interconnectedness. This theory views all things as multiplicities. Primarily this means that things consist of multiple constituents. However, in a deeper sense it means that things are constituted of multiple elements that are from others. Thus, this philosophy underlines the realization that a thing is not simply static, one of many (a singularity), but that it is the one constituted of the many others. Laurel Schneider (2008) notes that multiplicity is "not the same as 'the many' ... [but] results when things-ones-so constitute each another that they come to exist (in part, of course) because of one another" (p. 143).

This idea is deeply based in Alfred North Whitehead's (1978) philosophy of organism. The most famous quotation of his work highlights the nature of multiplicity: "The many become one, and are increased by one" (p. 21). That is, the one comes to exist as it integrates the many (others) into itself, and this one also becomes one of the many, becoming a part of the other. For Whitehead, this process is ongoing, and is a process through which ones are ever becoming "novel entities" (p. 21). Hence, the theory of multiplicity gives us two interesting insights: First, others are already in me, and I am in them. Second, all of us are constantly becoming new as we continue being interconnected to one another. These insights are revolutionary. They reject essentialism and nullify essentialists' fear of change. They also enable us to envision a better "us" tomorrow. In multiplicity, the closure of the system, which essentialists argue keeps their identity safe and sustainable, is unnatural and can happen only transiently. To make something unnatural possible requires power, and this particular kind of power often involves violence. Instead, it is only reciprocal relationships that form, sustain, and rejuvenate us.

This approach transforms our understanding of identity. It especially emancipates one's religious identity from a false assumption and treatment of essentialism. One's religious identity, which is 
a multiplicity, is already formed with many "others" and is constantly changing as one continues to interact with the world beyond self. Thus, unlike the claims of the essentialists, there is neither purely intrinsic essence in one's religious identity nor a reason why the religious identity should avoid interactions with and influences from others.

Moreover, a religious identity is not categorical. It rejects being identified as belonging to any "upper" category, for such an assumption generates a certain amount of reduction and removal. In an essentialist approach, a religious identity is considered to be categorical, which means it is one or the other. For example, if you are a Methodist, you may be invited and treated as nothing other than a Methodist. Your religious identity may be identified as a Protestant and a Christian because they are generic concepts to a Methodist. You are a Christian, a Protestant, and a Methodist, but nothing else. However, in the relational approach, such a classification does not work. For example, I am Presbyterian, but my religious identity is more than that. As a person who grew up in a Confucian culture where Buddhism and Shamanism permeate everything, my religious identity is more than a Presbyterian but not equal to the sum of all those religions. I am a multiplicity-a unique integration and embodiment of those religious elements, as well as of the multiple economic, political, and social contexts that I have experienced. Although I claim to be a Presbyterian that does not mean that I am 100 percent Presbyterian internally (Chung 2017). Moreover, my Presbyterian identity is not even like that of other Presbyterians. Thus, no overarching "shape" or "story" can define my religious identity (Lartey and Sharp 2017, p. 1). ${ }^{2}$ I am unmarred only when the multiplicity in me is fully affirmed and addressed.

The Whiteheadian relational approach also views a religion as a multiplicity, which is a radically different view from an essentialist approach. A religion is especially a multiplicity of multiplicities, for it is a gathering of many religious identities, which are multiplicities. As each individual is, so too a religion is formed with many "others," and it develops and changes as it constantly interacts with the others both inside and outside. The Korean Protestant tradition is a good example. It is formed with many pieces of Confucianism, Buddhism, and Shamanism, which appear in the ways in which Protestants practice and understand Christianity. These Protestants are also constantly changing as they interact with the other religions, cultures, societies, and so forth (Oak 2013; Min 2016). This view radically transforms our understanding of religion in several ways. One is that a religious tradition cannot be reduced to one particular teaching or shape. Religion is "polydox," which literally means "many opinions" and figuratively means "many right stories that are even contradictive" (Schneider 2011, p. 21). ${ }^{3}$ Thus the Korean Protestant tradition is one "story" of Christian faith, and it does not need to be and cannot be something else even though it seems contradictory to other Christian traditions.

Another transforming fact is that religion is fluid and changing. There is no point of return. We can respectfully remember a certain point of time in the past, but we cannot be exactly the same "shape" as we were at that time. The current Korean Protestant tradition is different from that of 50 years ago, for it encompasses and promotes different experiences. As Smith (1963) states, “The traditions evolve. Men's and [women's] faith varies. God endures" (p. 192).

Lastly, a religious tradition is already contextual, interreligious, and intercultural. No religious traditions are free from time, space, and indigenization. Based on their location and relation, the other religious pieces, socio-economic situations, religious and non-religious cultures, and historical events have become part of the religions.

In this relational approach, interaction is the natural mode of being and living. Our formation and transformation are inexplicable in the standalone claim, but explicable in the claim of togetherness. For this approach, interaction results in interconnection. Those involved become part of one another,

2 This claim also resonates with "multiple religious belonging", discussed by multiple scholars, including Catherine Cornille, Peter C. Phan, Francis X. Clooney, etc.

3 "Polydox" is a term that literally means many beliefs. This term implies the rejection and falsity of what is orthodox (there is only one right belief) or essentialism. 
as Jesus said, "you in me, and I in you" (John 14:20 NRSV). Since they mutually constitute one another and come to exist because of the other, they become the We-the community of "living together." In them are embodied three types of "living together": internal living together, external living together, and mutual living together. Internal living together is affirmed and enjoyed as one acknowledges in oneself multiple constituents including those from outside and lets them interact with one another inside oneself. External living together indicates the internal living together of the other person. It is external because one lives in the other person's selfhood. Mutual living together means that one and the other are living together or in tandem at this very moment and space. In relationalism, "living together" is existential.

\section{Interreligious Education with a Relational Approach}

The Whiteheadian relational approach based on the philosophy of multiplicity provides insightful answers to the essentialist problems addressed earlier.

1. To the problem of the why: The Whiteheadian relational approach changes the motivation of interreligious education from egocentric learning to human restoration. In this approach, interconnecting is a default mode of being and becoming. Thus, interreligious education that affirms and enhances interconnection recovers human beings from their "frozen" religious identities. This recovery takes one back to the law of nature and stands against the unhealthy, unjust, and violent state of the self and the society. Thus, interreligious formation and transformation are not an option but an avoidable necessity.

2. To the first problem of the who: This approach sees that interreligious education is for the participants, not their religions. Interreligious education is not an education between religions but an education between persons. The participants need not be either representatives or experts of their religions. They are welcome to come as they are. They simply need to come as homo religiosus, or human beings who care about life, death, meaning, suffering, and relate with religious teachings in their own ways.

3. To the second problem of the who: This approach embraces everyone, including atheists, "nones," those who consider themselves to be "spiritual but not religious," and so forth. This is the case because the perspective of multiplicity blurs the boundaries of religion. Further, this education is not about essence, nor is it about religion. This education is for human beings-all human beings. In this education, a binary education such as an education between Jews and Christians, or a ternary education such as an education among Christians, Jews, and Muslims, does not appear. It is always a multi-nary education, in which no one remains the same but everyone is affected by interaction with others.

4. To the problem of the what: In this approach, the doctrines, confessions, and tenets of a religion are not the primary subjects one learns. The primary subjects of study are human beings-the participants who are the "living human documents" (Boisen). Interreligious education is about learning who the participants are and how they and I are interrelated. That is the first way to learn a religion and avoid the violence of reductionism.

5. To the problem of the future: In a Whiteheadian relational approach, interreligious education is for relationship — to be the We. Thus, interreligious encounters and learning are ongoing tasks. Interreligious education is neither about agreement and disagreement, nor about commonality and difference. It is for relationship, which eventually results in transformation of the self, the other, and their relationship. They become another one. They are constantly moving toward being more ethical and religious, or ethically religious.

In sum, this relational approach enables educators to imagine interreligious education to be more humanizing, inclusive, and transformative. It is humanizing in the sense that this education liberates human beings from being submerged, objectified, and made invisible by the name of the religion. It is inclusive in that all human beings are fully acknowledged as they are and welcome to participate 
in the education whether they are religiously affiliated or not. It is transforming in the sense that this education moves participants to interact with one another in an ongoing way and to create a community of "living together," internally, externally, and mutually.

\section{Forward: A Conclusion}

I have introduced interreligious education as learning together how to live with one another by exchanging beliefs. This vision, however, encounters some problems when the education is implemented by essentializing religion. Such problems include the invisiblization of human beings against religions, the exclusion of idiosyncrasy in religious identities and spiritualities, and the incompatibility between its theory (separation) and practice (togetherness). A relational approach grounded in the philosophy of multiplicity provides a new framework within which those problems can be overcome. The primary difference is that it draws attention to real bodies in the relational web (human beings) rather than to an ideal and imaginative concept (religion). This change of view makes interreligious education more humanizing, inclusive, and transforming.

What does such a differently conceived interreligious education look like? Imagine that five Christians and five Muslims meet and learn together. Interreligious education using a relational approach would help us interpret these persons' meeting and learning as the education of ten religious people, of whom five self-identify as Christian and another five self-identify as Muslim. This would never be conceived as an instance of education between Christianity and Islam. What is shared is not the story of Islam but the five different stories of human beings who self-identify as Muslim. The five people who self-identify as Christian may even learn more from one another than they learn from the five Muslims, for the differences between two Christians are sometimes greater than the differences between one particular Christian and one particular Muslim. Some of these persons may address their concerns about being identified simply as Christian or Muslim. This education will take that concern seriously. Facilitators will actively encourage the participants to navigate that concern in a deeper way, for the main concern of the education is not how close participants are to so-called "orthodoxy" of their religions. Nor is the concern to single out the religion with which the participants are affiliated. Instead, the main concern of such education is to what degree participants can encounter the self and the other honestly, holistically, relationally, and freely. In other words, the main concern is whether their humanness is fully valued and respected (Van der Ven 1994, p. 253).

From an essentialist perspective, interreligious education with a relational approach can be a "dangerous" education. Part of the reason is that the purpose of such education is not to reproduce the same identity among all participants. As mentioned earlier, the purpose of such education is to facilitate participants becoming new human beings. This is an education for transformation. This is where we find hope for the future of religion. Raimon Panikkar (1999) once said, "All crossings are dangerous, but there is no new life without maithuna" (p. xix). ${ }^{4}$ Najeeba Syeed, associate professor of interreligious education at Claremont School of Theology, made a similar point: "[W]e must disarm the notion of a 'safe' classroom and disabuse students of an expectation of a risk-free learning experience" (Syeed 2014). However, one must note that this education is conceived as "dangerous" only when one sees it from a perspective of essentialism. From a perspective of relationalism, this education is daring and even revolutionary to the extent that it would even allow "the right to change one's own religion" (Van der Ven 1994, p. 254).

Some may argue that having both an essentialist approach and a relational approach in interreligious education might be beneficial. In general, I would disagree with that argument because these approaches are based on two different metaphysical ideas that are incompatible with each other. However, such an argument makes sense first, if by it one means that it is still important and necessary to learn things such as the tenets or core teachings of a religion. I would certainly agree

4 Maithuna means deep union in Sanskrit. 
with that idea if it is assumed that those tenets, core teachings, or whatever is to be claimed as the "essence" of the religion, are not the unchanging truth but what Smith (1963) calls the "cumulative tradition" whose nature is constructive, pluralistic, multilayered and, therefore, multivocal (p. 194); and second, if by it one means that learning between adherents or members of two or three particular religious groups is still needed and valuable in some contexts. I have no doubt that we continue to need such an education. However, Whitehead would say that such an education must include remembering and celebrating the differences among individuals in the same group.

Funding: This research received no external funding.

Acknowledgments: This research could be finished by the generous support of the Louisville Institute and the Pacific School of Religion.

Conflicts of Interest: The author declares no conflict of interest.

\section{References}

Abu-Nimer, Mohammed, and Renáta Katalin Smith. 2016. Interreligious and Intercultural Education for Dialogue, Peace and Social Cohesion. International Review of Education 62: 393-405. [CrossRef]

Allport, Gordon W. 1954. The Nature of Prejudice. Cambridge: Addison-Wesley Pub. Co.

Berling, Judith A. 2004. Understanding Other Religious Worlds: A Guide for Interreligious Education. Maryknoll: Orbis Books.

Boys, Mary C., and Sara S. Lee. 1996. The Catholic-Jewish Colloquium: An Experiment in Interreligious Learning. Religious Education 91: 421-66. [CrossRef]

Boys, Mary C., and Sara S. Lee. 2006. Christians and Jews in Dialogue: Learning in the Presence of the Other. Woodstock: SkyLight Paths Publishing.

Chalik, Lisa, Sarah-Jane Leslie, and Marjorie Rhodes. 2017. Cultural Context Shapes Essentialist Beliefs about Religion. Developmental Psychology 53: 1178-87. [CrossRef]

Chung, Jae Hyun. 2017. Jong-Gyo Shin-Hak Ip-Mun (Teaching Theologies of Religions). Seoul: Via.

Durka, Gloria. 2010. The Philosophical and Theoretical Aspects of Interreligious Education. In International Handbook of Inter-Religious Education. Edited by Kath Engebretson, Marian de Souza, Gloria Durka and Liam Gearon. International Handbooks of Religion and Education. New York: Springer, pp. 1-4.

Felderhof, Marius C., ed. 1985. Religious Education in a Pluralistic Society: Papers from a Consultation on Theology and Education Held at Westhill College, Selly Oak. London: Hodder and Stoughton.

Fowler, James W. 1981. Stages of Faith: The Psychology of Human Development and the Quest for Meaning. San Francisco: Harper \& Row.

Fuchs, Stephan. 2001. Against Essentialism: A Theory of Culture and Society. Cambridge: Harvard University Press. Heschel, Abraham Joshua. 1966. No Religion Is an Island. Union Seminary Quarterly Review 21: 117-34.

Kagan, Henry Enoch. 1950. Changing the Attitude of Christian toward Jew: A Psychological Experiment in Interreligious Education. New York: Central Conference of American Rabbis.

Kagan, Henry Enoch. 1952. Changing the Attitude of Christian toward Jew: A Psychological Approach through Religion. New York: Columbia University Press.

Kujawa-Holbrook, Sheryl A. 2014. God beyond Borders: Interreligious Learning among Faith Communities. Eugene: Pickwick Publications.

Lartey, Emmanuel Y., and Melinda A. McGarrah Sharp. 2017. Unleashing Belonging: Liberating Identities from Categorical Captivities. Journal of Pastoral Theology 27: 1-2. [CrossRef]

Mikva, Rachel S. 2018. Six Issues That Complicate Interreligious Studies and Engagement. In Interreligious/Interfaith Studies: Defining a New Field. Edited by Eboo Patel, Jennifer Howe Peace and Noah J. Silverman. Boston: Beacon Press, pp. 124-36.

Min, Anselm K. 2016. Korean Religions in Relation: Buddhism, Confucianism, Christianity. New York: SUNY Press.

Nipkow, Karl Ernst. 1991. Stage Theories of Faith Development as a Challenge to Religious Education and Practical Theology. In Stages of Faith and Religious Development: Implications for Church, Education, and Society. New York: Crossroad, pp. 82-98.

Oak, Sung-Deuk. 2013. Making of Korean Christianity: Protestant Encounters with Korean Religions, 1876-1915. Waco: Baylor University Press. 
Panikkar, Raimon. 1999. The Intrareligious Dialogue. New York: Paulist Press.

Patel, Eboo. 2007. Acts of Faith: The Story of an American Muslim, the Struggle for the Soul of a Generation. Boston: Beacon Press.

Patel, Eboo, and Patrice Brodeur, eds. 2006. Building the Interfaith Youth Movement: Beyond Dialogue to Action. Lanham: Rowman \& Littlefield Publishers.

Patel, Eboo, and Cassie Meyer. 2017. Teaching Interfaith Leadership. In Teaching Interreligious Encounters. AAR Teaching Religious Studies. Oxford and New York: Oxford University Press.

Pollefeyt, Didier, ed. 2007. Interreligious Learning. Leuven: Leuven University Press.

Pugliese, Marc A., and Alexander Y. Hwang, eds. 2017. Teaching Interreligious Encounters, 1st ed. New York: Oxford University Press.

Schneider, Laurel C. 2008. Beyond Monotheism: A Theology of Multiplicity. London: Routledge.

Schneider, Laurel C. 2011. Crib Notes from Bethlehem. In Polydoxy: Theology of Multiplicity and Relation. Edited by Laurel C. Schneider and Catherine Keller. New York: Routledge, pp. 19-35.

Smith, Wilfred Cantwell. 1963. The Meaning and End of Religion: A New Approach to the Religious Traditions of Mankind. New York: Macmillan.

Sterkens, Carl. 2001. Interreligious Learning: The Problem of Interreligious Dialogue in Primary Education. Leiden: Brill. Swidler, Leonard. 1991. Death or Dialogue: From the Age of Monologue to the Age of Dialogue. Grand Valley Review 6: 57-68.

Syeed, Najeeba. 2014. The Politics of Interreligious Education. Spotlight on Theological Education. March. Available online: https://www.aarweb.org/publications/spotlight-on-theological-education-march-2014-thepolitics-of-interreligious-education (accessed on 7 July 2017).

Thompson, Norma H., ed. 1988. Religious Pluralism and Religious Education. Birmingham: Religious Education Press. Van der Ven, Johannes A. 1994. Religious Values in the Interreligious Dialogue. Religion E Theology 1: 244-60.

Van der Ven, Johannes A., and Hans-Georg Ziebertz. 1994. Religiöser Pluralismus und interreligiöses Lernen. Weinheim: Beltz Deutscher Studienverlag.

Whitehead, Alfred North. 1978. Process and Reality: An Essay in Cosmology. Edited by David Ray Griffin and Donald W. Sherburne. New York: Free Press.

Wielzen, Duncan, and Ina Ter Avest, eds. 2017. Interfaith Education for All: Theoretical Perspectives and Best Practices for Transformative Action. Rotterdam: Sense Publishers.

(C) 2019 by the author. Licensee MDPI, Basel, Switzerland. This article is an open access article distributed under the terms and conditions of the Creative Commons Attribution (CC BY) license (http://creativecommons.org/licenses/by/4.0/). 